\title{
STUDIES IN HONOUR OF PETER E. RUSSELL ON HIS 80TH BIRTHDAY
}

\author{
Presentation \\ Julian Weiss \\ University of Virginia
}

"omnia secundum litem fiunt"

The essays gathered here from Peter Russell's friends, colleagues, and former students pay tribute to a man who has made a substantial contribution to scholarship on one of the key texts of the late Middle Ages and early Renaissance. That contribution to Celestina studies has not taken the form of a major monograph (though the preface to his recent edition is of monographic length), but has been made in other modes: in a series of responses to major books--review articles on the seminal works by Bataillon, Lida de Malkiel, and Gilman; in half-adozen or so pioneering articles on Rojas's play, its cultural milieu and reception; in his fine 1991 Castalia edition; and in his inspirational teaching, both in England and the United States.

This is not the occasion for either summary or developed account of all Peter Russell's publications on Celestina: their relation to his other articles and books on the fifteenth and sixteenth centuries, their historicist methods and goals, or how his work might intersect with future research. But--for me, as a former student--one of the many memorable qualities of his scholarly writing on Celestina has been and continues to be its deeply critical stance. A critical spirit suffuses his chosen forms of publication: reviews and articles where new and clearly defined questions can be framed, and where contemporary readings and received opinions can be engaged. To read his essays over the past thirty or so years is to get a sense of 
participating in the process of research and debate--so it is apt that this tribute should be in Celestinesca, whose pages record the continuing discussion on Rojas's book.

And the questions Peter Russell poses are central ones, of continuous relevance. As one whose research has been divided equally between history and literature, his writings have often brought to the fore the difficult relationship between the approach of the historian and that of the literary critic. The grounds of that relationship have evolved considerably since his reviews of the books by Lida de Malkiel (1978b [1964]) and Gilman (1978e [1975]), where, inspired by a skeptical empiricism, and supported by a sure yet unobtrusive command of historical documentation, he most trenchantly stakes a claim for social history. But the methodological issue that underpins his response to those scholars is still a pressing one, to which students of medieval and Renaissance Spain should urgently return in view of the various 'new historicisms' of literary scholars, and the changing practice of history itself.

On another level, many of Peter's most suggestive questions have emerged through his scrupulous attention to the detail of the literary work. Most recently (1989), spurred on by a textual incongruence, he asks "why did Celestina move house?" And this query leads on to speculation about the real urban setting of Rojas's world, where the author did so much to cover his historical tracks. Conversely, the starting point is often a larger socio-cultural problem, which then feeds back into our understanding of textual detail. Perhaps the most famous instance of this is his article on witchcraft, in which the historical documentation not only sheds light upon the early modern obsession with magic but also makes us think in a different way about how Rojas's text might actually work. There is another line of inquiry running through Peter's historicist readings of literature (and it is one to which my own research owes a special debt): this is his interest in the reception of Celestina in the century and a half that followed its composition. His study of James Mabbe's English translation (1953a), together with a broader overview of seventeenth-century interest in Spanish literature (1953b), should encourage us to explore further the social and political conditions that shaped the way other countries responded to the literature of the first European imperial power. Although these two studies were written before the development of reception theory, they connect with it in important and fruitful ways. I for one am sorry that they were not 
given a wider audience by being republished in Temas de ' $L a$ Celestina', especially in view of his prefatory (and characteristically challenging) remark that the subject "es capaz de proporcionarnos, de vez en cuando, datos que nos hacen dudar de la validez de algunas teorías generales sobre la literatura española de dicha época bastante divulgadas en la crítica peninsular" (1978: 7).

The articles that have had most impact on subsequent research are, perhaps, those on magic (1978a [1965]) and law (1978c [1976] and 1978d). Dorothy Severin's article in the present volume attests to the increasing importance attached nowadays to the theme of magic in Celestina (an interest inspired in part by recent rethinking about the cultural homogeneity of the Golden Age). Similarly, the current research by Ivy Corfis and others shows the continued value of Peter Russell's groundbreaking essays on the Celestina comentada and the legal studies of Fernando de Rojas. Magic and law: how well these two phenomena symbolize the tensions of a work caught between the opposing and complementary forces of chaos and order! And how well their presence in the text captures the ambiguity that Peter places at the heart of Rojas's book. For although these studies into magic and law were undertaken in part to show how contemporary or near contemporary readers could have responded to Celestina, the complexities and potential meanings of the titerary work are never entirely reduced to those historical responses. It is wholly characteristic of Peter's approach that the introduction to his edition closes with an emphasis upon that deep-rooted ambiguity which resists any single totalizing interpretation:

Puede concluirse que la crítica celestinesca debe resignarse a que, en el plano ideológico, no puede haber soluciones definitivas, sólo posibilidades. ¿Será que el gran descubrimiento de los autores de $L C$, herederos de una cultura dogmática, fue que el escepticismo no sólo era postura intelectual factible sino que también era capaz de desvelar nuevas y fecundas perspectivas $y$ formas literarias?

And it is characteristic too that this conclusion should be phrased as a question: this is a sure sign of the scholar's belief in the creative power of doubt, just as the following sentence shows his sensitivity to the interplay between past and present, as well as his reluctance to conflate them: 
Una edad en que se puede asertar, con Roland Barthes, que la literatura es, por definición, ambigua, verá, desde luego, en la compleja ambigüedad de $L C$ una explicación a lo menos parcial de su genialidad, no una señal de un fallo artístico ni una serie de enigmas que es deber del crítico resolver de modo definitivo.

It will be clear from statements such as these that readers will not find in his recent edition an attempt to use it as an obvious platform for a personal summation of the work's meaning (which may dismay some). Rather it has a propadeutic function, being produced to encourage and facilitate further critical thinking about Celestina, regardless of the personal approaches and interests which individual readers might bring to bear. Acknowledging his own debt to undergraduate and graduate students (1991: 178), the principal goal of his copious annotation is to elucidate the literal level of the text. Thus, his notes do not engage polemically with conflicting interpretations of specific passages. However, just as his emphasis on the text's ambiguity does not collapse into bland relativism, so he never pretends that complete neutrality is either achievable or desirable: his philological scholarship is at the service of interpretation (1991: 14).

By bringing out the richness of the play's verbal texture, Peter Russell puts us in a position to continue exploring the ways in which the work interweaves the language of official authority with a range of other, more subversive voices. (It reminds us that he himself is not interested just in history written from above, but also in life on the margins: in addition to his research into witchcraft, there is, among many others, his study on the poesía negra of Rodrigo de Reinosa (1978f); and it is significant that he called attention as far back as 1964 to the involvement of the Catholic Monarchs in prostitution (1978b: 288-89), a topic which is now receiving increased attention.)

The paradox, for him, was that "el empuje inicial de esta apertura hacia las clases bajas o marginadas venía del estudio de la comedia latina y del ambiente universitario en general" (1991: 152). And in the present volume, Louise Fothergill-Payne pursues this paradox by showing how Rojas participated in what Bakhtin called "la joyeuse littérature recréative des écoliers." Her wide-ranging study examines the various modulations and effects of that liberating 
laughter of the carnivalesque described by the Russian critic. And it opens the way for further research into the limits of that liberation, and its historical determinants.

For his part, David Hook demonstrates how historical documents can 'transilluminate' the details of a literary text, but in doing so they can complicate issues rather than simply resolve them. Continuing his research into Arthurian onomastics, he takes up the suggestion of Russell and others that Tristán may be one of play's "nombres hablantes" (1991: 96). However, Hook's archival research shows that Tristán was one of the commonest literary names at this time, and this fact raises questions about the extent of its literary overtones in Celestina: do we read it through the prism of Arthurian legend, or was the name something more akin to a dead metaphor? This question concludes a study whose value lies in part in the way characterization is shown to be a textual process, in part in the way Tristán is fully integrated into the thematic and structural web of the work.

Jeremy Lawrance elucidates the meaning of the authorial claims for didactic intent. He does so by invoking contemporary critical practice and theory, particularly the incipits of the work's most important generic model, the humanist comedy, and the medieval accessus to Terence. The fact that these critical prologues were concerned not with Christian but with secular ethics, and more particularly with civic order and public morality, lays the basis for a compelling reading of specific episodes. But his study moves beyond its initial premisses, and forces us to consider the much more profound problem of how class relationships are depicted by Rojas, and where the author's sympathies might lie.

Social readings of a different order are offered by James Burke and Dorothy Severin. In an overview of the work's relation to European witchcraft of the time, the latter develops Peter Russell's observation that Celestina is a sorceress, not a witch. But she reformulates the problem of definition by asking where the empowered female characters stand in relation to a patriarchal social order. Severin finds that Rojas's attitude is ambivalent: on the one hand, she attributes to the author a "perverse pleasure in his alternative society" of women; on the other, she shows how the alleged empowerment fails, and how female liberation has limited results. 
James Burke arrives via a different route at a similar conclusion in his study on the failure of maternal influence (in so doing, he is developing his recent work on patriarchal structures in Celestina). A starting point for some fascinating and far-reaching conclusions is found in a seemingly small detail relating to a secondary character (Areúsa's wandering womb in Act VII). Drawing upon a wide range of cultural and anthropological evidence, as well as psychoanalytic theory, he argues that the mal de la madre stands for the inversion of a symbol of stability and productive generation. Like the previous piece, this article does not foreclose the problem of how gender relations are established and put under pressure in the text, but rather it provokes us to examine the issue further.

As Alan Deyermond explains, the late Keith Whinnom's essay derives from unfinished work from the 1960s (and is a poignant reminder of a mind constantly in motion). It engages with scholarship that still exerts an influence upon contemporary readings (e.g. Lida de Malkiel, Castro Guisasola, and Gilman), and addresses an issue that in spite of intervening work of the past twenty-five years is still worth pursuing (as Lawrance's contribution attests): namely, Celestina's debt to humanist comedy, and to Terence. Keith Whinnom's critical summary of what the work owes to its generic antecedents endorses the conclusions of Lida de Malkiel, even as it modifies them. For Whinnom's conclusion is that Rojas's debt was probably assumed via the Margarita poetica of Albrecht von Eyb, a point which helps us nuance our understanding of the process of literary transmission.

Quite apart, therefore, from the significance of their different approaches and conclusions, the tribute paid to Peter Russell by the present writers is that they share his critical stance toward the task of literary scholarship. With one obvious exception, their essays are part of ongoing research projects, and develop ideas on which they have recently published elsewhere. Also, like Peter himself, the contributors display a keen eye for the mutually illuminating textual detail and the historical moment. This shared spirit of inquiry and creative doubt should endure amidst the current fruitful proliferation of theoretical methods, and indeed should sustain it. 
P. E. RUSSELL ... PRESENTATION 7

\section{WORKS CITED}

Russell, Peter E. (1953a) "A Stuart Hispanist: James Mabbe." Bulletin of Hispanic Studies, 30: 78-84

----. (1953b) "English Seventeenth-Century Interpretations of Spanish Literature." Atlante, 1: 65-77

---. (1978) Temas de 'La Celestina' y otros estudios. Del 'Cid' al 'Quijote'. Barcelona: Editorial Ariel

----. (1978a [1965]) "La magia, tema integral de La Celestina." Temas, 241-76

----. (1978b [1964]) "Tradición literaria y realidad social en La Celestina". Temas, 277-91

---. (1978c [1976]) "El primer comentario crítico de La Celestina: cómo un legista del siglo XVI interpretaba la Tragicomedia." Temas, 293-321

----. (1978d) "La Celestina y los estudios jurídicos de Fernando de Rojas." Temas, 323-40

-..-. (1978e [1975]) "Un crítico en busca de un autor: reflexiones en torno a un reciente libro sobre Fernando de Rojas." Temas, $341-75$

-.--. (1978f [1973]) "La 'poesía negra' de Rodrigo de Reinosa." Temas, $377-406$

----. (1989) "Why Did Celestina Move House?" The Age of the Catholic Monarchs 1474-1516: Literary Studies in Memory of Keith Whinnom. Ed. Alan Deyermond and Ian Macpherson. Liverpool: Liverpool University Press. 151-61

----. (ed). (1991) Comedia o Tragicomedia de Calisto y Melibea. Madrid: Castalia 


\section{セレスティーナ}

欲望の悲喜劇

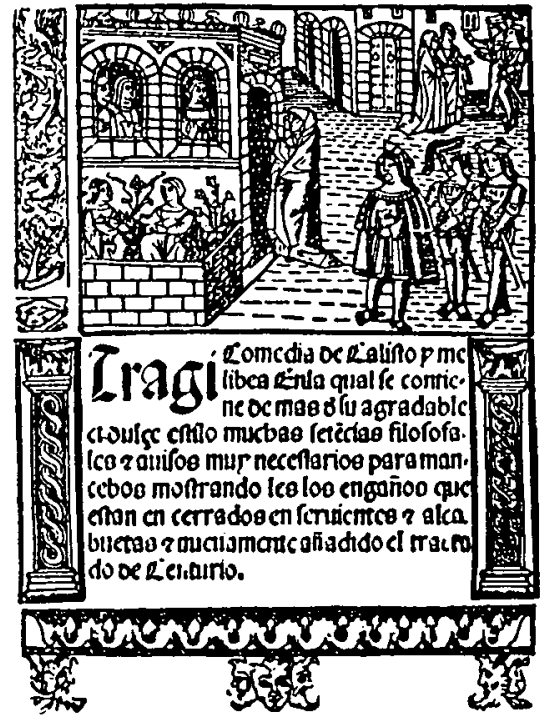

フェルナンド・テ・ロハス

岡 村一 訳

中川著占

Portada de la traducción japonesa

de Hajime Okamura, 1990. 